\title{
Effect of Chemical Presevatives on Service Life of Selected Wood Species Treated against Pests and Diseases
}

\author{
Ukoima, N. H. ${ }^{1} \&$ Uko, E. R. ${ }^{1}$ \\ ${ }^{1}$ Department of Forestry and Environment, Faculty of Agriculture, Rivers State University of Science and \\ Technology, Port Harcourt, Nigeria \\ Correspondence: Ukoima, N. H., Department of Forestry and Environment, Faculty of Agriculture, Rivers State \\ University of Science and Technology, Port Harcourt, Nigeria. E-mail: rijmanconsult@yahoo.com
}

Received: September 25, 2012 Accepted: January 10, 2013 Online Published: February 5, 2013

doi:10.5539/enrr.v3n1p157

URL: http://dx.doi.org/10.5539/enrr.v3n1p157

\begin{abstract}
The effect of different chemical preservatives on service life of selected wood species was evaluated in a field plot at the Forestry research site, University of Uyo, Akwa Ibom, Nigeria. Three wood species, Triplochiton scleroxylon K. Schum (Obeche), Gmelina arborea Linn (Gmelina) and Terminalia ivorensis A Chew (IdigboBlack afara) were used for this study. Two chemical preservatives namely; acid copper chromate and copper citrate at concentrations of $0 \%, 0.37 \%, 0.75 \%$ and $1.5 \%$ each and a mixture of the two preservatives (mixed preservative) at the given concentrations were used in treating stakes of these wood species and their retentions determined. Service life of the stakes was evaluated at the end of six months and insect pest and fungi that infected them identified. The result indicated that obeche had the highest mean retention of $4.04 \mathrm{~kg} / \mathrm{m}^{3}$.The result also showed that the retention increased with increase preservative concentration, the highest retention of 6.80 $\mathrm{kg} / \mathrm{m}^{3}$ was obtained with mixed preservative at $1.5 \%$ concentration. Treated stakes of all the three wood species lasted for the six months of the experiment while the untreated stakes failed within the period. Highest service life rating of 10 (no termite (Cryptotermes cavifrons Bank) damage) and (-) (no fungal growth) was obtained with mixed preservatives at $1.5 \%$ concentration. Based on these findings the use of these preservatives at concentrations of $0.075 \%-1.5 \%$ to enhance service life is recommended.
\end{abstract}

Keywords: chemical preservatives, service life, Triplochiton scleroxylon, Gmelina arborea, Terminalia ivorensis

\section{Introduction}

Service life of wood is considered by Markstrom and Clark (1975) as the life span between utilization and failure of wood in service. Degroot and Dickernoof (1975) attributed most failure of wood to improper choice of wood for a particular end use, poor structural design, and poor or lack of wood protection (preservative treatment). Chirra (1995) therefore, opined that wood must be properly protected against wood destroying organisms by proper preservative treatment. Markstrom and Clark (1975) observed that the treated ponderosa fence posts had longer service life than untreated posts. Also, Pastoret (2005) cited many examples where the service life of wood used for construction were significantly increased by treatment with preservatives. Furthermore, the study of Akhter (2005) on preservative treatment of rubber wood, Havea brasillensis, showed that rubber wood had its service life greatly increased through this process.

Wood is priced for multiple uses, and is bio-degradable. Therefore, it should be given appropriate preservative treatment when used under conditions favorable to biodegradation agents such as decaying fungi, insect pests and marine borers. The choice of appropriate chemical preservatives and treatment procedures that will ensure good preservative retention and maximum service life in treated wood is critical in achieving adequate wood protection (Chirra, 1975).

Other uses of wood are furniture making, construction and building. Triplochton scleroxlon K. Schum (Obeche) of the family Triplochitonaceae, Gmelina arborea Linn (Gmelina) of the family verbanaceae and Terminalia ivorensis A. Chev (Idigbo-Black Afara) of the family combretaceae are widely used wood species with good qualities but may be readily destroyed in use if not well preserved.

This research is therefore aimed at evaluating the effect of these chemical preservatives on service life of these wood species in Nigeria. 


\section{Materials and Methods}

\subsection{Experimental Site}

The study was conducted at the Forestry Research site of the university of Uyo, Akwa Ibom State, Nigeria situated between latitudes $5^{\prime} 17^{\circ} \mathrm{S}$ and $5.27^{\circ} \mathrm{N}$ and longitudes $7.27^{\circ} \mathrm{W}$ and $7.58^{\circ} \mathrm{E}$ (Uyo city development Authority, 1998). It is characterized by two seasons, the wet or rainy season which lasts for about nine months and a short dry season during which the state is covered by dry to dusty harmattan winds .Rainfall is heavy ranging between $2000 \mathrm{~mm}$ to $3000 \mathrm{~mm}$. The rainfall pattern is bimodal, starting in March and ending in November with a short period of moisture stress in August traditionally referred to as August break (Udo, 1970, 1989). Temperatures are uniformly high throughout the year with slight variations between $260^{\circ} \mathrm{C}$ and $280^{\circ} \mathrm{C}$. High relative humidity is also common.

\subsection{Collection and Preparation of Wood Samples}

Freshly converted timber of Triplochiton scleroxylon (Obeche), Gmelina arborea (Gmelina) and Terminalia ivorensis (Idigbo) were obtained from commercial timber dealers in Port Harcourt, Sapele and Uyo. Several samples measuring $2.5 \mathrm{~cm} \times 10 \mathrm{~cm} \times 70 \mathrm{~cm}$ were prepared (Sawn and planed) each timber species. The prepared samples were stacked in an open shed and air-dried for three months to reduce the moisture content of the wood. Wood samples for the study were randomly selected from these pools of prepared samples.

\subsection{Preparation of Chemical Preservatives}

\subsubsection{Acid Copper Chromate (ACC) Acquisition and Preparation}

These preservatives were obtained from commercial dealers. The concentrate contains $320 \mathrm{~g}$ of copper Oxide $(\mathrm{CuO})$ and $680 \mathrm{~g}$ chromium trioxide $\left(\mathrm{CrO}_{3}\right)$ in one liter of solution. The concentration of $0.37 \%, 0.75 \%$ and $1.5 \%$ were prepared by diluting the concentrate with water to the appropriate level. Several liters of each concentration were prepared for the experiment (DeGroot et al., 2000). ACC was designated B, and the four levels $0 \%, 0.37 \%$, 0.75 and $1.5 \% \mathrm{~B}_{1}, \mathrm{~B}_{2}, \mathrm{~B}_{3}$ and $\mathrm{B}_{4}$ respectively.

\subsubsection{Copper Citrate (CC) Acquisition and Preparation}

Copper citrate (CC) was also obtained from commercial dealers. It contains $620 \mathrm{~g}$ Copper oxide (CuO) and 380 $\mathrm{g}$ citric acid in one liter of solution. The required concentrations, $0 \%, 0.37 \%, 0.75 \%$ and $1.5 \%$ were prepared as described in the case ACC above.

The preservative was designated $\mathrm{C}$ with four levels $0 \%, 0.37 \%, 0.75 \%$ and $1.5 \%$ designated $\mathrm{C}_{1}, \mathrm{C}_{2}, \mathrm{C}_{3}$ and $\mathrm{C}_{4}$ respectively.

\subsubsection{Mixed Preservative Preparation}

Mixed preservative was prepared by mixing $50 \%$ by volume of ACC preservative B and $50 \%$ by volume of CC at given concentrations $(0 \%, 0.37 \%, 0.75 \%$ and $1.5 \%$ each) to obtain their respective mixed solutions.

\subsection{Determination of Retention of Chemical Preservatives in Selected Wood Species}

Forty-eight (48) wood samples from each wood species were randomly selected from pools of prepared wood samples for treatment. There was no bias as to the portion of the tree (heartwood or sapwood) from which samples were obtained. The samples were subjected to preservative treatment using soaking (steeping) process in their respective treatment vessels for twenty-four (24) hours (Chirra, 1995; Koch, 1972). After treatment, they were air-dried for one week for reconditioning. The basis of weight gain of the treated stakes at different concentrations of preservatives as adopted by Markstrom and Clark (1975) and DeGroot et al. (2000) was used to compute the retentions of preservatives in these species.

\subsection{Evaluation of Effect of Chemical Preservatives on Service Life of Selected Wood Species}

Treated samples and their controls were exposed to field test by installing them $30 \mathrm{~cm}$ deep and $40 \mathrm{~cm}$ above the ground in experimental plot. The experiment was observed monthly for six months. Data on fungal and insect attacks were collected for the period. Rating used to visually estimate percentage of cross sections of stakes (samples) that were destroyed by termites (Cryptotermes cavifrons Bank) were in accordance with APWA standard (1998). Fungal growth rating method of profuse (+++), moderate $(++)$, scanty $(+)$ and no growth (-) was used to visually estimate growth of fungi (APWA, 1998). Fungi were isolated and identified as shown by (Barnett \& Hunter, 1972). Rating used to visually estimate the percentage (\%) of damage by termite was; 10 Non, wood sound, 1-2 nibbles, 9 - Slight feedings -3\%, $8-3 \%-10 \%, 7-10 \%-30 \%, 6-30 \%-50 \%, 4-50 \%-$ $70 \%$, - > 75\% failure (break) (AWPAE,1993) 


\section{Results and Discussion}

Obeche had the highest mean retention $\left(4.04 \mathrm{~kg} / \mathrm{m}^{3}\right)$ amongst all the preservatives used in the study and was significantly higher than those of Gmelina $\left(3.36 \mathrm{~kg} / \mathrm{m}^{3}\right)$ and Black afara $\left(2.98 \mathrm{~kg} / \mathrm{m}^{3}\right)$ (Table 1). This may be attributed to the influence of specific gravity among them. This supports the findings of Koch (1972) that wood with lower specific gravity retain more preservatives than those of higher specific gravity.

Table 1. Overall total and mean retention of the three preservatives in $\mathrm{kg} / \mathrm{m}^{3}$ by treated stakes of Obeche, Gmelina and Black afara

\begin{tabular}{llll}
\hline & Obeche $\left(\mathrm{A}_{1}\right)$ & Gmelina $\left(\mathrm{A}_{2}\right)$ & Black afara \\
& Retention $\left(\mathrm{kg} / \mathrm{m}^{3}\right)$ & Retention $\left(\mathrm{kg} / \mathrm{m}^{3}\right)$ & Retention $\left(\mathrm{kg} / \mathrm{m}^{3}\right)$ \\
\hline Total & 194.21 & 161.36 & 143.08 \\
Mean & $4.04 \mathrm{a}$ & $3.36 \mathrm{~b}$ & $2.98 \mathrm{c}$ \\
\hline
\end{tabular}

* Mean followed by the same letter in the same row is not significantly different (LSD at $\mathrm{P}<0.05)$.

The retention of preservatives in treated stakes increases with increased concentrations of ACC concentrations (Tables 2 and 3). This agrees with the book of DeGroot et al. (2000) who observed that increase in concentrating of water borne preservatives led to increased retention of preservatives in treated stakes of Douglas-fir.

Table 2. Mean retention of Acid Copper Chromate preservative in $\mathrm{kg} / \mathrm{m}^{3}$ by Obeche, Gmelina and Black afara treated stakes

\begin{tabular}{llll}
\hline Acid Copper Chromate & Obeche $\left(\mathrm{A}_{1}\right)$ & Gmelina $\left(\mathrm{A}_{2}\right)$ & Black afara $\left(\mathrm{A}_{3}\right)$ \\
Preservative concentration $(\%)$ & Mean Retention $\left(\mathrm{kg} / \mathrm{m}^{3}\right)$ & Mean Retention $\left(\mathrm{kg} / \mathrm{m}^{3}\right)$ & Mean Retention $\left(\mathrm{kg} / \mathrm{m}^{3}\right)$ \\
\hline $0.00\left(\mathrm{~B}_{1} \mathrm{C}_{1}\right)$ & $0.00 \mathrm{~d}$ & $0.00 \mathrm{~d}$ & $0.00 \mathrm{~d}$ \\
$0.37\left(\mathrm{~B}_{2} \mathrm{C}_{1}\right)$ & $2.30 \mathrm{c}$ & $1.60 \mathrm{c}$ & $1.26 \mathrm{c}$ \\
$0.75\left(\mathrm{~B}_{3} \mathrm{C}_{1}\right)$ & $4.60 \mathrm{~b}$ & $4.00 \mathrm{~b}$ & $2.60 \mathrm{~b}$ \\
$1.50\left(\mathrm{~B}_{4} \mathrm{C}_{1}\right)$ & $6.50 \mathrm{a}$ & $5.00 \mathrm{a}$ & $4.20 \mathrm{a}$ \\
\hline
\end{tabular}

Table 3. Mean Retention of Copper Citrate preservative $\left(\mathrm{kg} / \mathrm{m}^{3}\right)$ by Obeche, Gmelina and Black afara treated stakes

\begin{tabular}{llll}
\hline Copper Citrate $(\mathrm{A} 3)$ & Obeche $\left(\mathrm{A}_{1}\right)$ & Gmelina $\left(\mathrm{A}_{2}\right)$ & Black afara $\left(\mathrm{A}_{3}\right)$ \\
Preservative concentration $(\%)$ & Mean Retention $\left(\mathrm{kg} / \mathrm{m}^{3}\right)$ & Mean Retention $\left(\mathrm{kg} / \mathrm{m}^{3}\right)$ & Mean Retention $\left(\mathrm{kg} / \mathrm{m}^{3}\right)$ \\
\hline $0.00\left(\mathrm{~B}_{1} \mathrm{C}_{1}\right)$ & $0.00 \mathrm{~d}$ & $0.00 \mathrm{~d}$ & $0.00 \mathrm{~d}$ \\
$0.37\left(\mathrm{~B}_{1} \mathrm{C}_{2}\right)$ & $2.40 \mathrm{c}$ & $1.72 \mathrm{c}$ & $1.54 \mathrm{c}$ \\
$0.75\left(\mathrm{~B}_{1} \mathrm{C}_{3}\right)$ & $4.72 \mathrm{~b}$ & $4.10 \mathrm{~b}$ & $4.00 \mathrm{~b}$ \\
$1.50\left(\mathrm{~B}_{1} \mathrm{C}_{4}\right)$ & $6.54 \mathrm{a}$ & $6.23 \mathrm{a}$ & $6.00 \mathrm{a}$ \\
\hline
\end{tabular}

LSD at $\mathrm{P}<0.05$.

For mixed preservative, retention in the treated stakes varied with concentrations of ACC and CC preservatives in mixture (Table 4).

This agrees with Wahua (1999) that when changes in the level of one factor (chemical) affect the other's response to treatment and vice versa in the mixture, there is an interaction. Treated stakes that attained ground contact exposure retention requirement $\left(6.40 \mathrm{~kg} / \mathrm{m}^{3}\right)$ stipulated by APWA standard (1998) and supported by Canadian Institute of Treated Wood (CITW) (1990) did so at the highest concentrations (1.5\%) of treating solution (Tables 2, 3 and 4). This could be attributed to the limitation of non-pressure method of preservative application as stated by Chirra (1995) that non-pressure process gives lower retention of preservatives in treated wood than does pressure process as the later forces more preservative into the wood than the former. Therefore at 
the highest concentration more preservative was retained even with lower penetration. Retention of preservative treated stakes were significantly higher than those of untreated stakes in the three wood species.

Table 4. Mean retention of mixed preservatives $\left(\mathrm{kg} / \mathrm{m}^{3}\right)$ in Obeche, Gmelina and Black afara treated Stakes

\begin{tabular}{llll}
\hline Mixed & Obeche $\left(\mathrm{A}_{1}\right)$ & Gmelina $\left(\mathrm{A}_{2}\right)$ & Black afara $(\mathrm{A} 3)$ \\
Preservative concentration $(\%)$ & Mean Retention $\left(\mathrm{kg} / \mathrm{m}^{3}\right)$ & Mean Retention $\left(\mathrm{kg} / \mathrm{m}^{3}\right)$ & Mean Retention $\left(\mathrm{kg} / \mathrm{m}^{3}\right)$ \\
\hline $0.00\left(\mathrm{~B}_{1} \mathrm{C}_{1}\right)$ & $0.00 \mathrm{~d}$ & $0.00 \mathrm{~d}$ & $0.00 \mathrm{~d}$ \\
$0.37\left(\mathrm{~B}_{2} \mathrm{C}_{2}\right)$ & $2.20 \mathrm{c}$ & $1.80 \mathrm{c}$ & $\mathrm{S} 1.25 \mathrm{c}$ \\
$0.56\left(\mathrm{~B}_{2} \mathrm{C}_{3}\right)$ & $1.50 \mathrm{c}$ & $1.10 \mathrm{c}$ \\
$1.50\left(\mathrm{~B}_{1} \mathrm{C}_{4}\right)$ & $2.00 \mathrm{c}$ & $6.23 \mathrm{a}$ & $6.00 \mathrm{a}$ \\
$0.94\left(\mathrm{~B}_{2} \mathrm{C}_{4}\right)$ & $6.54 \mathrm{a}$ & $2.50 \mathrm{c}$ & $2.00 \mathrm{c}$ \\
$0.56\left(\mathrm{~B}_{3} \mathrm{C}_{2}\right)$ & $3.80 \mathrm{~b}$ & $2.00 \mathrm{c}$ & $1.80 \mathrm{c}$ \\
$0.75\left(\mathrm{~B}_{3} \mathrm{C}_{3}\right)$ & $2.70 \mathrm{bc}$ & $4.50 \mathrm{~b}$ & $4.10 \mathrm{~b}$ \\
$1.13\left(\mathrm{~B}_{3} \mathrm{C}_{4}\right)$ & $5.50 \mathrm{a}$ & $4.40 \mathrm{~b}$ & $4.00 \mathrm{~b}$ \\
$0.94\left(\mathrm{~B}_{4} \mathrm{C}_{2}\right)$ & $5.90 \mathrm{a}$ & $2.30 \mathrm{c}$ & $4.00 \mathrm{~b}$ \\
$1.13\left(\mathrm{~B}_{4} \mathrm{C}_{3}\right)$ & $3.00 \mathrm{~b}$ & $5.73 \mathrm{a}$ & $4.27 \mathrm{~b}$ \\
$1.50\left(\mathrm{~B}_{4} \mathrm{C}_{4}\right)$ & $5.80 \mathrm{a}$ & $6.40 \mathrm{a}$ & $6.30 \mathrm{a}$ \\
\hline
\end{tabular}

* Means followed by the same letter in the same column are not significantly different (LSD at $\mathrm{P}<0.05$ ).

Fungi were observed to grow more profusely $(+++)$ on moist chamber cultures of stakes that were not treated with preservatives than those that were treated (Tables 5,6 and 7).

This is attributed to the inhibitory effect of the preservatives on growth. This agrees with the work of Clausen and Green (2003) that preservative treated wood placed in ground contact exposure resisted attack by both fungi and termite (Cryptotermes cavifrons Bank) thus extending its service life than the untreated wood. Increase in concentration of preservatives resulted in decrease in intensity of fungal growth with three preservatives (Tables 5,6 and 7). There was no growth (-) on cultures of stakes treated with highest concentration $(1.5 \%)$ in the three chemical preservatives. Increase in concentration might have resulted in increase in retention of preservatives which provided sufficient toxicity that stopped the growth of fungi on treated stakes. This supports the finding of Pastoret (2005) that good retention of preservative in treated wood offer better protection to the wood.

Obeche was observed to suffer the least damage by termite (Cryptotermes cavifrons Bank) and was sufficiently different from Gmelina and Black afara, (i.e. 7.29, 6.54 and 6.44 respectively) (Table 8). Treated stakes had higher rating of performance (service life) against termite (Tables 9, 10 and 11). Increase in concentration of preservatives also led to reduction on damage treated stakes by termites (Cryptotermes cavifrons Bank).

Stakes treated with highest concentration of combined preservative (1.5\%) offered the best protection (10.00) against termite attack (Table 11).

Treated stakes especially with good retentions were observed to resist termite and fungal attack and also lasted for the period of experiment (six months) than the untreated stakes which failed before the end of the period. This is due to the protection offered by the chemical preservatives to treated woods thus enhancing their service life more than that of the untreated stakes. Markstrom and Clark (1975) had reported that treated ponderosa pine fence post had longer service life than untreated fence post.

Varying degrees of damage especially by termites (Cryptotermes cavifrons Bank) were observed on stakes that did not meet ground contact retention treatment requirement. This is in line with the observation of DeGroot et al. 2000 and DeGroot and Woodward, 1999 that Douglas-fir stakes that did not meet standard retention requirement before being exposed to service test were more easily degraded by decay fungi and termites (Cryptotermes cavifrons Bank). 
Table 5. Fungal growth grading from moist chamber cultures of Obeche, Gmelina and Black afara stakes treated with Acid Copper Chromate preservative

\begin{tabular}{llll}
\hline \multicolumn{5}{c}{ Growth from cultures } \\
$\begin{array}{l}\text { Acid Chromate } \\
\text { Preservative Concentration (\%) }\end{array}$ & & & \\
\hline $0.00\left(\mathrm{~B}_{1} \mathrm{C}_{1}\right)$ & +++ & +++ & +++ \\
$0.37\left(\mathrm{~B}_{2} \mathrm{C}_{1}\right)$ & +++ & ++ & ++ \\
$0.75\left(\mathrm{~B}_{3} \mathrm{C}_{1}\right)$ & - & + & + \\
$1.50\left(\mathrm{~B}_{4} \mathrm{C}_{1}\right)$ & - & - & - \\
\hline
\end{tabular}

Table 6. Fungal growth from moist chamber cultures of Obeche, Gmelina and Black afara stakes treated with Copper Citrate preservative

\begin{tabular}{llll}
\hline \multicolumn{5}{c}{ Growth from cultures } \\
$\begin{array}{l}\text { Copper Citrate } \\
\text { Preservative Concentration (\%) }\end{array}$ & & & \\
\hline $0.00\left(\mathrm{~B}_{1} \mathrm{C}_{1}\right)$ & +++ & +++ & +++ \\
$0.37\left(\mathrm{~B}_{1} \mathrm{C}_{2}\right)$ & ++ & ++ & +++ \\
$0.75\left(\mathrm{~B}_{1} \mathrm{C}_{3}\right)$ & + & - & + \\
$1.50\left(\mathrm{~B}_{1} \mathrm{C}_{4}\right)$ & - & - & - \\
\hline
\end{tabular}

Table 7. Fungal growth grading from moist chamber cultures of Obeche, Gmelina and Black afara Wood treated with mixed preservative

\begin{tabular}{llll}
\hline \multicolumn{5}{c}{ Growth on cultures } \\
Mixed & Obeche & Gmelina & Black afara \\
Preservative Concentration (\%) & & & \\
\hline $0.00\left(\mathrm{~B}_{1} \mathrm{C}_{1}\right)$ & +++ & +++ & +++ \\
$0.37\left(\mathrm{~B}_{2} \mathrm{C}_{2}\right)$ & ++ & ++ & + \\
$0.56\left(\mathrm{~B}_{3} \mathrm{C}_{2}\right)$ & ++ & ++ & ++ \\
$0.75\left(\mathrm{~B}_{3} \mathrm{C}_{3}\right)$ & - & + & + \\
$1.13\left(\mathrm{~B}_{3} \mathrm{C}_{4}\right)$ & - & - & - \\
$0.94\left(\mathrm{~B}_{4} \mathrm{C}_{2}\right)$ & - & + & - \\
$1.13\left(\mathrm{~B}_{4} \mathrm{C}_{3}\right)$ & - & - & - \\
$1.50\left(\mathrm{~B}_{4} \mathrm{~B}_{4}\right)$ & - & - & - \\
\hline
\end{tabular}

Table 8. Total mean rating of overall performance of treated wood species (Obeche, Gmelina and Black afara) against termites (Cryptotermes cavifrons )

\begin{tabular}{llll}
\hline Rating & Obeche $\left(\mathrm{A}_{1}\right)$ & Gmelina $\left(\mathrm{A}_{2}\right)$ & Black afara $\left(\mathrm{A}_{3}\right)$ \\
\hline Total & 350 & 314 & 309 \\
Mean & $7.29 \mathrm{a}$ & $6.54 \mathrm{~b}$ & $6.44 \mathrm{~b}$
\end{tabular}

* Means followed by the same letter in the same row are not significantly different (LSD at $\mathrm{P}<0.05$ ). 
Table 9. Mean rating of performance (service life) of Obeche, Gmelina and Black afara stakes treated with Acid Copper Chromate preservative against termite (Cryptotermes cavifrons )

\begin{tabular}{llll}
\hline & Obeche $\left(\mathrm{A}_{1}\right)$ & Gmelina $\left(\mathrm{A}_{2}\right)$ & $\begin{array}{l}\text { Black afara }\left(\mathrm{A}_{3}\right) \\
\text { Acid Copper Chromate }\end{array}$ \\
Preservative concentration $(\%)$ & $($ Mean $)$ & $\begin{array}{l}\text { Rating } \\
(\text { Mean })\end{array}$ & $\begin{array}{l}\text { Rating } \\
(\text { Mean })\end{array}$ \\
\hline $0.00\left(\mathrm{~B}_{1} \mathrm{C}_{1}\right)$ & $3.33 \mathrm{c}$ & $1.33 \mathrm{~d}$ & $0.00 \mathrm{a}$ \\
$0.37\left(\mathrm{~B}_{2} \mathrm{C}_{1}\right)$ & $3.33 \mathrm{c}$ & $2.67 \mathrm{c}$ & $1.33 \mathrm{c}$ \\
$0.75\left(\mathrm{~B}_{3} \mathrm{C}_{1}\right)$ & $8.00 \mathrm{~b}$ & $9.67 \mathrm{a}$ & $8.33 \mathrm{~b}$ \\
$1.50\left(\mathrm{~B}_{4} \mathrm{C}_{1}\right)$ & $10.00 \mathrm{a}$ & $10.00 \mathrm{a}$ & $9.67 \mathrm{a}$ \\
\hline
\end{tabular}

LSD at $\mathrm{P}<0.05$.

Table 10. Mean rating of performance of Obeche, Gmelina and Blaack afara stakes treated with Copper citrate preservative against termite (Cryptotermes cavifrons Bank)

\begin{tabular}{|c|c|c|c|}
\hline & Obeche $\left(A_{1}\right)$ & Gmelina $\left(\mathrm{A}_{2}\right)$ & Black afara $\left(\mathrm{A}_{3}\right)$ \\
\hline Acid Copper Chromate & Rating & Rating & Rating \\
\hline Preservative concentration (\%) & (Mean) & (Mean) & (Mean) \\
\hline $0.00\left(\mathrm{~B}_{1} \mathrm{C}_{1}\right)$ & $3.33 \mathrm{~d}$ & $1.33 \mathrm{~d}$ & $0.00 \mathrm{~d}$ \\
\hline $0.37\left(\mathrm{~B}_{1} \mathrm{C}_{2}\right)$ & $4.00 \mathrm{c}$ & $2.67 \mathrm{c}$ & $1.33 \mathrm{c}$ \\
\hline $0.75\left(\mathrm{~B}_{1} \mathrm{C}_{3}\right)$ & $8.67 \mathrm{~b}$ & $6.33 b$ & $6.00 \mathrm{~b}$ \\
\hline $1.50\left(\mathrm{~B}_{1} \mathrm{C}_{4}\right)$ & $10.00 \mathrm{a}$ & $10.00 \mathrm{a}$ & $9.00 \mathrm{a}$ \\
\hline
\end{tabular}

LSD at $\mathrm{P}<0.05$.

Table 11. Mean rating of performance (service life) of mixed preservative treated stakes of Obeche, Gmelina and Black afara against termites (Cryptotermes cavifrons Bank.)

\begin{tabular}{|c|c|c|c|}
\hline & Obeche $\left(A_{1}\right)$ & Gmelina $\left(\mathrm{A}_{2}\right)$ & Black afara $\left(\mathrm{A}_{3}\right)$ \\
\hline Acid Copper Chromate & Rating & Rating & Rating \\
\hline Preservative concentration (\%) & (Mean) & (Mean) & (Mean) \\
\hline $0.00\left(\mathrm{~B}_{1} \mathrm{C}_{1}\right)$ & $3.33 \mathrm{~d}$ & $1.33 \mathrm{~d}$ & $0.00 \mathrm{e}$ \\
\hline $0.37\left(\mathrm{~B}_{2} \mathrm{C}_{2}\right)$ & $5.33 \mathrm{c}$ & $4.67 \mathrm{c}$ & $2.67 \mathrm{~d}$ \\
\hline $0.56\left(\mathrm{~B}_{2} \mathrm{C}_{3}\right)$ & $7.00 \mathrm{~b}$ & $5.00 \mathrm{c}$ & $5.67 \mathrm{c}$ \\
\hline $0.94\left(\mathrm{~B}_{2} \mathrm{C}_{4}\right)$ & $8.33 \mathrm{ab}$ & $5.33 \mathrm{bc}$ & $4.67 \mathrm{c}$ \\
\hline $0.56\left(\mathrm{~B}_{3} \mathrm{C}_{2}\right)$ & $6.00 \mathrm{bc}$ & $7.67 \mathrm{~b}$ & $7.67 \mathrm{~b}$ \\
\hline $0.75\left(\mathrm{~B}_{3} \mathrm{C}_{3}\right)$ & $9.00 \mathrm{a}$ & $6.60 \mathrm{~b}$ & $9.33 \mathrm{a}$ \\
\hline $1.13\left(\mathrm{~B}_{3} \mathrm{C}_{4}\right)$ & $10.00 \mathrm{a}$ & $8.30 \mathrm{ab}$ & $9.33 \mathrm{a}$ \\
\hline $0.94\left(\mathrm{~B}_{4} \mathrm{C}_{2}\right)$ & $7.67 \mathrm{~b}$ & $6.67 b$ & $9.00 \mathrm{a}$ \\
\hline $1.13\left(\mathrm{~B}_{4} \mathrm{C}_{3}\right)$ & $7.67 \mathrm{~b}$ & $9.00 \mathrm{a}$ & $9.33 \mathrm{a}$ \\
\hline $1.50\left(\mathrm{~B}_{4} \mathrm{C}_{4}\right)$ & $10.00 \mathrm{a}$ & $10.00 \mathrm{a}$ & $10.00 \mathrm{a}$ \\
\hline
\end{tabular}

* Means followed by the same letter in the same column are not significantly different (LSD at $\mathrm{P}<0.05$ ).

\section{Conclusion}

The study on the effect of different chemical preservatives on social service life of selected wood species has demonstrated that the service life of Obeche, Gmelina and Black afara can be enhanced through the use of Acid Copper Chromate, Copper Citrate and mixtures of the two preservatives (Mixed preservative) with standard 
retention of these preservatives in treated wood for specific use.

This study has been able to show that of the three wood species, Obeche had the best preservative effect with highest mean retention followed by Gmelina and Black afara and their resistance (performance) to attack by fungus Trichoderma sp and Cryptotermes cavifrons Bank (termite) in the study site followed the same order.

Therefore, in order to effectively enhance the service life of wood, the use of chemical preservatives with standard retentions is highly desirable.

\section{References}

Akhter, K. (2005). Preservative Treatment of Rubber Wood (Hevea brasillensis) to increase its service life. Bangladesh Forest Institute, Sholosaher Chittagong, Bangladesh. pp. 1-8.

American Wood Preservers' Association. American Wood Preservers' Association Book of Standards. (1993). Standard Method of evaluating wood preservatives by field tests with stakes. Grandury. p. 150.

Barnett, H. L., \& Hunter, B. B. (1972). Illustrated genera of imperfect fungi. (3rd ed.). Burgess publishing Company, Minneapolis, Minnesota, USA. pp. 34-91.

Canadian Institute of Treated Wood (CITW). (1990). Wood Preservation. Brunswick Publishing House, Canada. pp. 7-15.

Chirra, F. (1995). Ohio Prestige Applicator Training (Wood Preservation Student Workbook), Williams Country, 112 W. High Street Bryan, OH 43506. p. 42.

Clausen, C. A., \& Green, F. I. (2003). Copper tolerance of brown-rot fungi: Time course of Oxalic acid production. International Bio deterioration and Biodegradation, 51, 145-149. http://dx.doi.org/10.1016/S0964-8305(02)00099-9

DeGroot, R. C., \& Dickerhoof, H. E. (1975). Wood deterioration problems in single-family Houses in Mobile Country, Alabama, Southern Forest Expt. Sta. USDA Forest Service; Gulfport, Miss. p. 5.

DeGroot, R. C., Grawford, D. M., Norton, J., \& Keith, J. (2000). Five-year field trials using preservative treated second growth Douglas-fir exposed in ground contact in Australia. Forest Prod. J., 50, $46-53$.

DeGeoot, R. C., \& Woodward, B. (1999). Using Copper tolerant fungi to biodegrade wood treated with Copper-based preservatives. USDA Forest Service, Forest Product Laboratory, one Gifford Pinchot Drive, Madison, Wis. USA. pp. 1-9

Koch, P. (1972). Utilization of Southern Pines. Vol. 11 Processing. U.S. Department of Agriculture- forest service, Government Printing House, Washington D.C. 20402. pp. 200-280.

Markstrom, C. D., \& Clark, D. H. (1975). Service Life of Treated and Untreated Black Hills Ponderosa Pine Fence-posts: A Progress Report. Rocky Mountain Forest and Range Experiment Station, Fort Collins, Colorado. pp. 1-4.

Pastoret, J. (2005). Use of Treated Wood. School of Natural Resources, University of Missouri Extension, Missouri. pp. 1-5.

Udo, E. J. (1989). Tentative fertilizer recommendation for crops in Akwa Ibom. Task Force on Soils and Land use survey of Akwa Ibom State. pp. 10-20.

Udo, R. K. (1970). Geographical regions of Nigeria. Heinemann Educational Books. London: Morrison Gibb. Ltd. pp. 25-40.

Uyo Capital City Development Authority (UCCDA). (1998). No. 10 Esuene street, Uyo, Akwa Ibom State, Nigeria. p. 20.

Wahua, T. A. T. (1999). Applied Statistics for Scientific Studies. Afrika-Link Books, Owerri Ibadan- Abuja. Nigeria. pp. 129-191. 